\title{
The Logistic Management Strategy for Alternative Energy in Iraq
}

\author{
Hani Fadhil Jumaah Alshawi \\ Assistant Professor Dr., Accounting Department, Shatt-Al-Arab University College, Basra, Iraq \\ Email: dr.hanishawi@gmail.com
}

How to cite this paper: Alshawi, H.F.J. (2020) The Logistic Management Strategy for Alternative Energy in Iraq. Energy and Power Engineering, 12, 109-133. https://doi.org/10.4236/epe.2020.124009

Received: January 27, 2020

Accepted: April 26, 2020

Published: April 29, 2020

Copyright (c) 2020 by author(s) and Scientific Research Publishing Inc. This work is licensed under the Creative Commons Attribution International License (CC BY 4.0).

http://creativecommons.org/licenses/by/4.0/

\begin{abstract}
The current research attempts to prove that the alternatives to energy sources in most of the Arab world and Iraq is very abundant, such as wind, sunlight and hydropower, as well as some plants that contain energy-saving oils, such as the interesting "JATROPHA" which contains a high percentage of oils and is spread in Africa and has been cultivated in some countries of the region currently because they contain this energy which will describe the future of energy Future generations, tremendous energy that should not be wasted it must make the most of them. These are the most controversial signs where scientific indicators confirm that those who do not have knowledge of contemporary developments in the world is not intensifying their efforts to provide alternatives to energy, whose traditional sources are sure to be implemented sooner or later, and they have become one of the important steps for discussion and for most of the countries in the region. Surely they must prepare to move to the new class of servant class for the developed world. In light of this problem and the importance of what I mentioned above, the research aims to discover the importance of alternative energy sources in Iraq to achieve economic, environmental and civilizational returns. The important research hypothesis is summarized by the extent of the contribution of the industrial organizations researched in Basra in the use of alternative energy (clean and renewable) in order to achieve an increase in economic and social returns and reduce the causes of environmental damage.
\end{abstract}

\section{Keywords}

Renewable Energy, Industrial Organizations, The Logistic Management, Iraqi Sectors

\section{Introduction}

The academic motivation paves us for the search for clean alternatives to energy. 
What led me was the development of a feeling of anxiety about the polluting behaviors that surround us in Iraq, and showed its actions from diseases, epidemics, and dangers that were the result of reckless policies that threaten humans and the universe. Then it is our responsibility that, if you were, you were born

Feeling more anxious and anxious, in German universities, some universities, institutes and specialized centers in them have relied on discoveries of scientific research in the field of renewable energy.

Meanwhile, the German Higher Education Foundation (144) has a specialization in the field of wind, biological and solar energy where many Master's programs are directed to the degree of foreign students to meet the requirements of studying in this field.

And my studies in the following axis will be exposed to previous studies related to some of the targeted concepts as follows.

\section{Previous Studies}

Sustainability is considered a controversial issue in a lot of universities and this idea is obvious through scientific boards including the research centers and international conferences. Politicians and some other organizations occasionally call for joint work and private sectors could also contribute to application of sustainability and its standards. In this regard, the former UN secretary General Kofi Anan (2002) uttered that sustainability will be just a dream without the act of private sector.

I started to realize that by activation of the mixed sectors we could achieve tangible progress. Mixed sector has technology, funds and management capabilities to achieve the goal. In addition, it is non-monopolist and does not wait for the government's decisions [1].

Since alternative energy is the most important factor of (sustainability), researchers suggested that leaders and decision making people should pay much more attention to such crucial issue. It is then justifiable to choose an Iraqi study because it represent local fact. It deals with the environment in Iraq over all dimensions. We tried our best to bring forth a modern study that responds to the current conditions. The Iraqi studies in this regard are as follows:

First: solar energy doubles to 3000 Giga-watt [2]

1) This study stressed the environmental dimension relied on (the Earth) summit held by the UN in Reo De Jannero, 1992. One of its most important objectives was the control on production and vehicles use to reduce negative effects on environment resulted from pollutants emitted from vehicles. [2] suggested recommendations for pollution reduction and making green environment. It also introduced the government to new options for the improvement of environment in Iraq. options are outlined as follows:

2) Concentration on the western part of the country-building new housing complexes to hold thousands of families in Basra, Najaf, Ramadi, and Karbala. Farming lands are to be left for the production of food chain. 
3) Vertical building is required to eliminate land wasting. Roads and public places are required as well.

4) Relocation of factories including oil refineries to desert areas. In addition, oil and gas should be transported by special trucks and railway coaches instead of pipelines are likely to cause more pollution and oil spills.

5) Creating new living opportunities for farmers who choose the desert for new housing option. This is done by working out water wells, funding, constructing houses for agricultural engineers and farmers who later acquire these properties when successful agriculture is made. Cattle breeding industry is also supported and other facilities including schools, sanitation, healthcare centers, police stations are provided as well.

6) Utilizing of hygienically processed waste water for irrigation and even drinking.

The remaining water is pumped to marshes and dams are erected on both $\mathrm{Ti}$ gris and Euphrates where they flow into Shatt-el Arab at which a dam is also planned to be set in order to keep water inside the boundaries of Basra and prevent its ooze to the gulf.

I think that all people should have duty to keep local environment clean by soundly dealing with the increasing numbers of vehicles which entails building new roads with plants on both sides and good lighting. Furthermore, railways, operated by alternative energy, bridges and metro systems are planned to be build in bigger cities to reduce traffic congestions and eliminate light-crossroads because they are costly and fuel-consuming. If the number of crossroads, vehicles waiting and time taken to pass were identified then we would extremely be amazed at the wasted energy costs, let alone the potential risks caused by emitted gas pollution and engine noise.

Second: environment pollution: challenge and treatment [3] and [4]

This study is concerned with highlighting a serious problem-the negative part the human practice in deformation of the real world. Human has been meddling up with everything until the menace alarm of environmental pollution rung. Environmental pollution taking place everywhere, is considered to be dark side of the cultural development. According the study, the most prominent features of human intrusion in the environmental changes are the following.

1) The nature-consuming wars which took place when lands were full of biological, animal and plant fortunes which were formed over millions of years ago. Man got involved in changing the biological diversity so that it could be adapted to private needs. For example, cattle grazing may have ruined huge green areas.

2) The impact of modern technology on environment. Man ways of life and activities have had negative impacts concerning pollution of natural water resources caused by sewage water. The industrial wastes carried to rivers is another factor of environment pollution. Many species of fish, plants and other living beings because of the rising $\mathrm{PH}$ rate in river water. River Thames in the UK, for 
example was once one of the world's main sources of salmon but now it is hardly to find one salmon in it. In Iraq, a lot of animals, birds migrated or disappeared because of the reckless policies of the former regime.

3) Wars and fighting that frequently took place across Iraq also resulted in an immense destruction of environment, soil, plants and wild life. Farms were also ruined.

4) Oil extraction, exportation and circulation processes increased the pollution impact on people, atmosphere, and lands where oil residuals and harmful chemicals were produced by burning huge amounts of petroleum products

5) The increasing numbers of cities built on the rivers banks which caused damage to wide farming areas as it happened in district of "Abu al-Khaseeb in Basra" and wide areas across the country.

6) The inappropriate use of pesticides and chemical fertilizers in addition to the wastes chemical carried away into seas and rivers which, after being dissolved in water cause water contamination and may turn it into invalid water for human and animals. This is happening in Tigris, Euphrates and Shat el Arab in Iraq. In some parts the world, pure and unpolluted areas can be found where no human contaminating practices are observed. Thus human is and has been the basic reason for substantial damages made $\mathrm{n}$ the environment.

Thus, future generations are waiting for the predicted disasters of the irresponsible present and past generations' practices against the environment. In response, all scientific specialized centers in universities and civil communities organizations around the world have to have duties to clarify the percussions of potential disaster to the public and impose control on the industrial processes and practices of individuals.

\section{Conception of Research (philosophy of sustainable economy)}

The tight relationship between environment and development let to the emerging of the concept of (sustainability).The fourth principle established by (Rio De Janeiro conference, 1992 [5]), suggested that sustainability is achieved when associated with the environment protection.

Sustainability was first recognized by the World Committee for Environment and Development which called for achievement of development that satisfy the present generation's needs with no damage to the future needs. This conception was also emphasized through in the third principle. Sustainability was concerned with the necessary achievement of preserved rights for present and future generations. Thus the term (sustainability) is not only applicable to economic development, rather it further implies a wide range of issues involved in multidimensional conception to manage the economy, environment and society. These elements form the foundation of (Sustainability)

According to researchers, funding such projects could achieve huge beneficial outputs for all of us and consequently we can make use of advantages such as (quietness, availability, harmony and flexibility. etc.).

Consequently, the conception (sustainability) appears to have resulted from 
close relationship between development and environment which entails environment protection to achieve sustainability. The renewable energy is considered one of ways to protect environment. [6] [7].

The contemporary changes and-the huge developments and dramatic changes, emphasize more different future world than the current one. They will have a great impact on different areas and sectors. Our economy, society, environment, health, business and education will substantially affected by these changes which support the suspicion of the predicted danger-(running out) of natural energy reserves. It would therefore be familiar matter to highly consider the issue of energy.

Everyone around the world must be concerned about the future of energy resources. Energy is currently influencing our welfare and behavior and rather is touching the critical issues of societies.

After different parts of the world were severely inflicted by various disasters, which consumed the inherited resources and damaged the civil features, there have been increasing concerns about the critical area of (energy). An example of the natural disasters which had terrible effect on the environment is the Tsunami that hit Japan and the following explosion of "

Atomic plant or Japanese nuclear reactor Fukushima "nuclear reactor. Should this issue be ignored? Shall we be at alert to potential similar events and disasters? We live closer to one of the most dangerous nuclear reactors, the Iranian (Iran's nuclear reactor called the "Bushehr" reactor). Recent studies confirm that the city of Basra is most likely to get directly affected in case this reactor is blown up. The Iran's nuclear reactor "Bushehr" is situated at the biological belt of earthquakes as geographical facts confirm. In addition, there is the risk of continuous damages catching the Ozone layer and the resulting phenomena like the unusual climate changes.

\subsection{The First Part of the Research: Methodology and Previous Studies}

\section{Research Methodology}

\section{a) The Problem}

The energy currently present in Iraq is dilapidated energy and performs its function incorrectly and this will certainly lead to negative effects on the environmental and ethical aspects regarding the economic and social impacts accompanying them.

The research is interested in answering two important questions:

1) Is it possible to switch to alternative sources of current electric energy in Iraq?

2) Is it possible to discover alternative energy resources for use by Iraqi industrial organizations?

3) What are the chances of using alternative energy in Iraq and will it be achieved?

b) The research importance

This study is important in terms of many factors, among which are the following: 
1) Secure processing of information that predicts (oil running-out) and the products consumed by production operations by the year 2050 [8].

These predictions have been emphasized by most world's energy organizations including the German center of energy technology studies, which stimulates research on cheaper and cleaner recourses of energy [9].

2) The academic contribution in the scientific research that discovers new methods for environment preservation and sustainability for future generations.

3) Since solar energy is eco-friendly, it entails special interest in its sustainable use in Iraq as it is experienced in the developed countries and some other developing ones which had earlier initiatives in this respect.

4) An attempt to attract the attention of some state establishments, namely those in Basra such as Steel and Cast steel Co., Paper Factory and (the name of Iraqi factory is: Iben Majid) to the necessary support for energy resources.

The ministry of Electricity can not always be so active to supply these institutions with electric power when they can't offer any products. In the mean time are consuming parts of the national economy and budget and they will hopefully wake and contribute to the unsatisfied requirements of people.

\section{c) Aims of the research}

The research aims are divided into two groups:

1) The key aims which represent long run strategic objectives, they are:

- economic aims

- environmental aims

- social aims

Those ensure the right to conserve natural resources for the future generations 2) The Secondary Aims

- Conservation of the national economy and rationalizing energy resources consumption including natural resources

- Academic support for the establishment of corporate environmental culture in our institutions to achieve an inclusive well-planned development.

- Exploitation of science and technology for conservation of environment and natural recourses.

- Supporting the national energy-operating capacities in the different sectors

- Contribution to the development of energy researches to meet the citizens' increasing needs for electric power.

- Preparing to establish clean, advanced urbanization

- Coping with the world's ongoing developments

- Improvement of the people's living standards in Iraq

- Discovering an equivalent power source of the electrical power source by utilizing of the energy alternatives of wind, sun and water.

d) Research Limits (time and place)

1) Time Limits: The study started on $1^{\text {st }}$ December, 2018 and ended on $15^{\text {th }}$ January, 2019

2) Pace Limits: The study was applied to governmental offices which belong to the sectors shown in Table 1. The reasons for choosing the three sectors which are: 
- Those sectors are technically related to the subject in research.

- Work tasks experienced in those sectors are scientifically and practically correlated to the research matter.

According to Table 1, the percentage of engineers compared to that of other specializations reached its peak of $62 \%$. This can be attributed to the proficiency of those people. They are more concerned about the results for many reasons among which is that most of them are people in charge. Consequently the study results represent self-evaluation that can be relied on for decision making on performance improvement. The percentage of technicians (25\%) comes the second whereas the percentage of environmental researchers form $(13 \%)$ of the total rate of the investigated society.

e) The Research Society:

It included oil sector (SOC), electricity sector (directorate of electricity production and distribution in Basra and environmental sector represented by directorate of environment protection and improvement in southern area, Basra. The research society was limited to (321) individuals who are specialized in the above sectors.

\section{f) Research sample and data gathering method}

The research sample involved a group of specialist employees in the field of energy from different sectors. Since the nature of the study through which information credibility is affected by the sample individuals, understanding of the research matter and time devoted to the study, the random sample method was used by the investigated society individuals. The study tools were given out to (60) individuals of the society which comprise (321) people, (20) from each class or sector. This is supposed to meet the requirements to conduct the survey so that the number of partial group individuals should not be less than [7] [10].

Table 2 shows the details:

Survey forms were given out to the research sample individuals during working hours-starting from $14^{\text {th }}$ October to $20^{\text {th }}$ December, 2018. Only (50) valid responses were gained and used for analysis and thus total percentage of responses reached (83\%)—scientifically accepted [10].

\section{h) Research Variables}

1) The independent dimension (alternative energy requirements) and the related factors:

Table 1. Sample and society of research.

\begin{tabular}{|c|c|c|c|c|c|}
\hline No. & Sector & Area of work \& place & Specialization & Number & Percent age \\
\hline 1 & Oil & South Oil Co., Basra & Oil engineer & 130 & $40 \%$ \\
\hline 2 & Electricity & $\begin{array}{c}\text { Directorate of Electricity } \\
\text { production \& distribution/Basra }\end{array}$ & $\begin{array}{l}\text { Electrical } \\
\text { engineer } \\
\text { electrician }\end{array}$ & $\begin{array}{l}70 \\
80\end{array}$ & $\begin{array}{l}22 \% \\
25 \%\end{array}$ \\
\hline 3 & & $\begin{array}{l}\text { Directorate of environmental } \\
\text { protection/south area }\end{array}$ & $\begin{array}{l}\text { Environmental } \\
\text { researcher }\end{array}$ & 41 & $13 \%$ \\
\hline 4 & Environment & Basra & & 321 & $100 \%$ \\
\hline
\end{tabular}


Table 2. Research sample.

\begin{tabular}{|c|c|c|c|c|c|}
\hline No. & Sector & Field of work \& place & Specialization & Number & Rate \\
\hline 1 & Oil & SOC, Basra & Engineer & 20 & 0.333 \\
\hline \multirow{2}{*}{2} & \multirow{2}{*}{ Electricity } & Directorate of elect. & Engineer & 10 & 0.17 \\
\hline & & Production \& distribution & Technician & 10 & 0.17 \\
\hline \multirow[t]{2}{*}{3} & Environment & $\begin{array}{l}\text { Environment protection \& } \\
\text { improvement/Basra }\end{array}$ & $\begin{array}{l}\text { Environment } \\
\text { researcher }\end{array}$ & 20 & \\
\hline & & Total & (4) specializations & 60 & $100 \%$ \\
\hline
\end{tabular}

- The government policy towards traditional energy alternatives which is supposed to consider the burdening electricity crisis and the efforts backed up for solutions.

- Culture of society.

- Academic support from universities and scientific research centers.

- Financial support from state and informal society organizations.

2) The reliable dimension (sustainability foundations)

To keep the present generation needs balanced with the future ones, this sense should have been emphasized through the third principle (adopted by Rio De Janeiro conference, 1992) where a lot of issues were stressed to master the triangle (economy, environment and society).

The three basics of sustainability are [11]:

- Economic benefits.

- Environmental benefits.

- Social stability.

i) The hypotheses.

This study was concerned with the sole hypotheses: (The use of alternative, clean and renewable energy contribute to the achievement of increasing economic outcomes, improvement of social benefits and reduction of damages to the environment.

\section{j) The Study measure description and consistency test}

1) Study standard description

A questionnaire form was used to gather information based on future dimension represented in alternative energy supply requirements. The dimensions were symbolized by $(\mathrm{z} 1)$ and their sub variables by $(\mathrm{x} 1-\mathrm{x} 4)$ which are the government policy, society culture, academic support and funding. Measure standards were identified with two indicators per factor-total of (8) indicators assigned to statistics analysis symbols ( $c 1-c 8)$.

As for the reliable dimension (sustainability foundations-the alternative energy benefits) it was symbolized by (z2) and represented in the three dimensions, which were given symbols $(\mathrm{x} 5-\mathrm{x} 7)$.Those dimensions are the economic benefits, environment dimensions and social stability. I in addition, sub indicators were determined-two indicators per factor and the total number if indicators was [10]. They were given the symbols (c9 - c14). We relied on Rinses Lickert's stan- 
dard in which responses varies from 1 (I quite disagree) to 5: I quite agree). Then the individual responses of the sample were emptied in the statistic band matrices for social sciences (SPSS). i underlined the word which identify the item key.

Table 3 shows the research measure.

2) Based on the arbitrators' observations and propositions, some phrases were rephrased to comply with the Iraqi environment conditions. Number of Items obtained is (14) and thus the test of implicit harmony accuracy of the standard was conducted adopting Cronbach's Alph Coefficient. Conformity (harmony) rate reached (0.981) which is statistically acceptable proportion. Below is the mathematical formula of Cronbach's Alpha coefficient [12].

$$
\begin{aligned}
\mathrm{R} & =\text { range inter item correlation } \\
\mathrm{N} & =\text { number of arbitrators, }[1] \text { experts } \\
\mathrm{A} & =\text { Alpha Coefficient } \\
\mathrm{A} & =10.0 .841 / 1 .(10-1) \cdot 0.8841 \\
& =7.569+1 / 8.411 \\
& =8.569 / 8411
\end{aligned}
$$

\section{The consistency test, Alpha $=\mathbf{0 . 9 8 1}$}

Standard, Alpha $>0.75$ The two researchers adopted the statistical program for social sciences to analyze arbitrators' opinions and information for item accuracy measurement. Table 4 shows test results of research standard consistency.

Table 3. Research measurement tool.

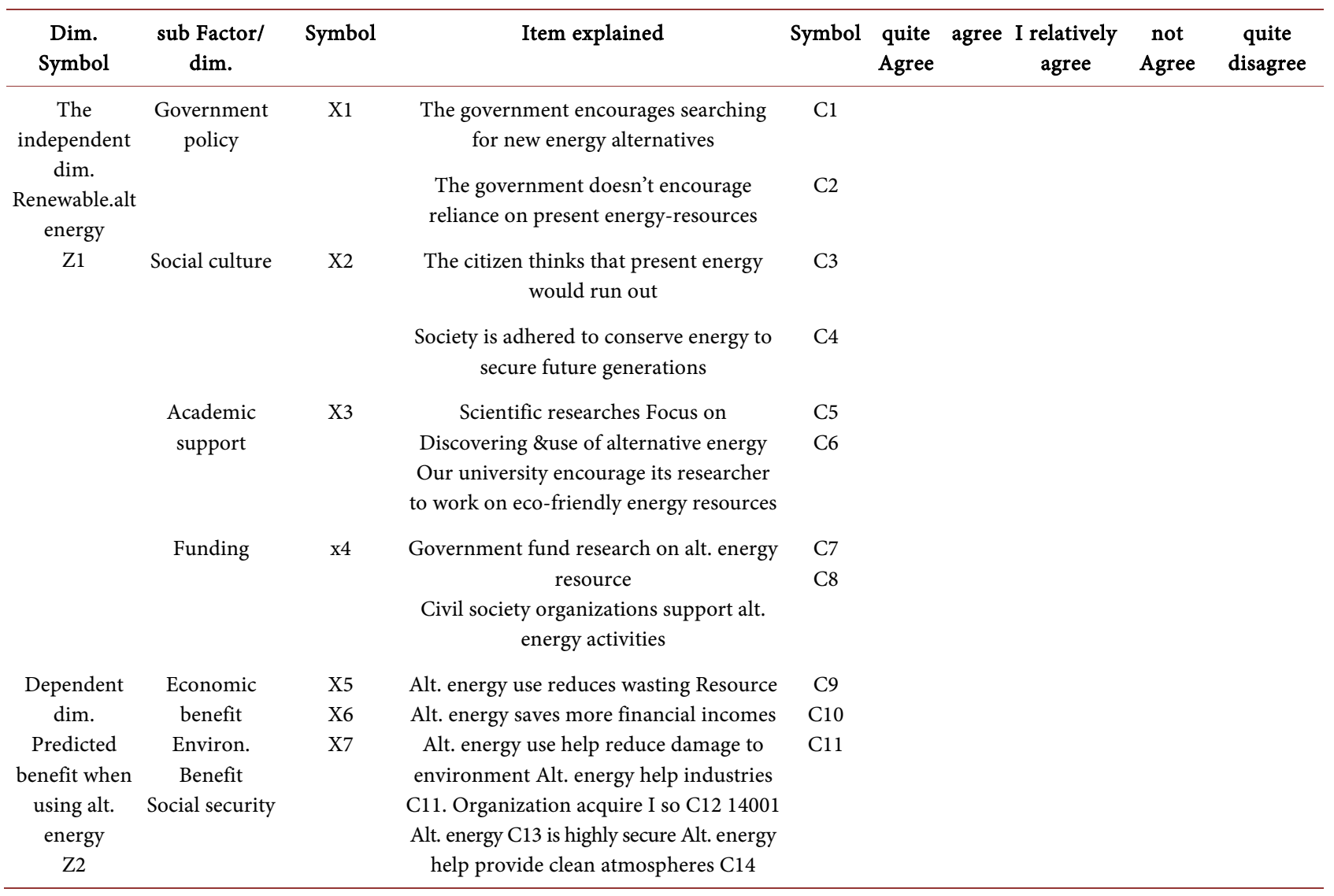


Table 4. Consistency test results $\mathrm{N}=60$.

\begin{tabular}{cccc}
\hline No. & Dimension & $\begin{array}{c}\text { Number of } \\
\text { items explained }\end{array}$ & $\begin{array}{c}\text { Value of } \\
\text { Alpha Cronbach }\end{array}$ \\
\hline $\mathbf{1}$ & Government policy & 2 & 0.791 \\
$\mathbf{2}$ & Society culture & 2 & 0.812 \\
$\mathbf{3}$ & Academic support & 2 & 0.833 \\
$\mathbf{4}$ & Financing & 2 & 0.844 \\
$\mathbf{5}$ & Economic benefits & 2 & 0.896 \\
$\mathbf{6}$ & Environmental benefits & 2 & 0.817 \\
$\mathbf{7}$ & Social security & 2 & 0.895 \\
& Total & 14 & 5.888 \\
Coefficient questionnaire consistency & & 0.981 & \\
\hline
\end{tabular}

Results: $-\mathrm{m}((\alpha))=0.8411$. Source: - spss program out puts.

The results appeared when $(\mathrm{t})$ was at mistake rate of $(0.01)$, confidence level at (0.99). Discrepancy rate appeared to be equal to international statistic reference, why? It resulted like that since that variation would unlikely be accidental except at a rate of $1 \%$. When it occurs at confidence level of 0.05 it implies confidence level of (0.95). The potential coincidence percentage is likely to be (5\%) and freedom range at level (9) equals (3.5); considering the freedom range $=(\mathrm{n}-1)$ $=(10-1)$ because there were 10 arbitrators. Thereby, the result comprise the total values of Alpha 5. 8888/number of dimensions $(7)=0.844$, average alpha for seven dimensions, (supposed average value $=3.00=$ standard average).

\subsection{Part Two: The Theoretical Side (Traditional and Alternative Energy) Comparative Overview}

The Concept of the current traditional energy and alternative energy resources

\section{1) Concept and management of current alternative energy}

Energy is referred to by different conceptions according to the user's point of view. For ordinary people, it is a product like gasoline, coal or electricity; for an engineer energy is the driving power for engines and the temperature necessary for furnaces. Energy is interpreted differently by an economist, for whom energy is considered as the essential key for national welfare; and the economic development wheel for any country, without energy may probably be broken down absolutely defined the term energy as everything that provide us with light and warm, carry us from a place to another and help extract and prepare food [13].

Energy represents the invisible face of the universe non-living beings. There are many kinds of energy — chemical, mechanical, thermo, solar, electrical and photo energy. It is possible for keen researcher to differentiate between traditional (non-renewable energy) such as petrol, coal, metals, natural gas and chemicals and alternative renewable energy which includes wind power, solar energy, water and waves, underground water and vital mass energy. 
As for energy management conception, it is varied in meaning. It is defined as the management process of wheel of equipment and devices which help in movement and transportation [14] and [15].

This conception further expanded to refer to energy management as inclusive and thorough process concerned with energy production, distribution, transmission and use.

In the meantime, energy is referred to as the management of earth's surface.

The emphasis on energy subject in the past few decades but it has not been studied widely until the seventies of the last century.

\section{2) Reasons for the increasing consumption of traditional energy}

There is a directional relationship between the population proportion and energy different uses. As population rate increases along with the industrial development energy consumption increases [16] suggests two main reasons for the increasing rate of energy use:

a) The huge rise of population around the world caused by the improvement of living standards and urban development in addition to the availability wide use of technology.

b) Unplanned energy handling policies by individuals and governments.

3) The disadvantages of traditional energy overuse:

Overuse of traditional energy leads to many damages, they are:

- Environmental damages caused by electric power generation processes.

- The high expenses allocated for electric power consumption and distribution [17].

- Energy waste. Unnecessary consumption of energy is experienced particularly for household purposes.

- The possible risks threatening human lives in case of electric shocks.

\section{4) Rationalizing of energy consumption and environment protection}

The first positive initiative of energy manipulation, rationalization and problem solving attempts started in response to concerns triggered by the experts of Japanese 'Toyota after the fuel crisis across the world in 1970 and the following success they achieved. They economized energy production processes and established moral measures to tackle overconsumption of energy.

Rationalizing energy requires controlling or curbing seven types of energy wasting factors which intercept Toyota's production line. They are outlined as follows: [18]

- Limitation of energy waste related to overproduction (unnecessary production).

- Reduction of unnecessary saved energy.

- Reduction of time wasted by waiting workers and stand by machines.

- Elimination of unnecessary movement of personnel and machines.

- Reduction of unnecessary materials mobility.

- Prevention of energy wasted on manufacturing of unimportant objects.

- Controlling the wasted energy on unnecessary processes.

The above Japanese company aimed at putting an end to these seven energy- 
wasting factors. Those developments led to wake up the international community to face inescapable facts energy run-out and look for efficient alternative energy resources which do not have negative impacts on environment sustainability. Man have to reconsider options regarding protection of environment and people throughout generation. Some people may be questioning this concentration on this issue where there are huge oil and gas reserves which may be sufficient for more generations to come. Actually this issue is too much concerned with the common economic benefits for generations and above all how significantly this topic is related to environment.

It is thus decisively inferred that rationalizing the currently used traditional energy is considered the first sound step to shift attention to the alternative energy consumption and that is our research matter.

I proposed that this step may lead to a solution to the age problem and that of Iraq particularly. Our hypotheses will be substantiated later through the remaining research items.

\section{5) Energy consumption rationalizing policies}

Turning to the use of alternative energy is normally preceded by rationalizing of traditional energy use stage.

This stage requires the following policies:

a) Planning to encourage institutions and individuals to use electrical power typically and efficiently using modern power-saving devices.

b) Institutions and individuals are encouraged to eliminate the use of traditional fuels

c) Education of societies regarding energy-saving ways.

d) Presenting financial support for alternative energy use options such as solar power, wind power and water power to produce clean electric power.

e) Introducing policy to change the way individuals and institutions consume power

f) Encouraging industrial sectors to adopt recycling programs which reduce energy consumption.

g) Using gas and solid waste to produce energy.

Extracted fuel types like gas, oil and coal are considered the most important ones used to generate power because of their abundance in addition to the available technology required. But this type of fuel definitely cause serious environmental problems during the burning processes which emit harmful gases to environment and (climate) and people

\section{6) Energy rationalizing mechanisms}

There are many useful energy rationalizing methods that can be adopted by industrial businesses and all related people an even families, they are

a) Using better isolation in buildings.

b) Using less thermo-conductive bricks may lead to save approximately $40 \%$ of energy and it is also important to ventilation means.

c) Using economical lighting devices which save more energy. 
d) Using solar energy for cooling and heating.

e) Using diesel engines instead of gasoline engines may also save more energy.

f) Recycling wastes (metals, paper and glass) could save energy.

\section{8) Alternative Energy Resources (the green sector)}

According to ([2] [6]) the most important resources of alternative energy which are:

- wave energy

- natural heat energy

- biological residuals and energy products

- Hydrogen gas

- green energy

- solar power

- wind power

- heat power in seas and oceans

- ebb and tide power

- inside-ground heat power

- noise power

- biological power.

The herb (Jatropha) for example is an alternative energy. In Sudan, it is considered as a strategic source for the production of alternative power. Farmers often are surprised to see the rapid growth of this plant and often it is cut down and thrown away. Jatropha curcas is a small tree. It has leaves similar to those of grape with nut-like fruits that contain seeds full of bitter oil. The oil rate in the seeds reaches $35 \%-40 \%$ at ripeness time. The oil can be used as a source of fuel that burns without harmful fumes and it produces fifth the amount of $\mathrm{O}_{2}$ produced by burning petrol. Thus it helps save energy and protect environment. Ketem, a tentative project supported by German research center, in south Darfur, Sudan proved apparent success in this field [19] [20].

\section{3) Concept, Importance and Resources of Alternative Energy \\ I) Concept}

Alternative energy is defined as the energy derived from renewable natural resources which are unlikely to run out. Since it does not produce accompanying harmful gases or other pollutants as those produced by petrol, it is used widely in the developed countries and some developing countries. Recently the use of alternative energy has been widely familiar to face the threatening climatic changes.

It is worthy of mentioning that the current use of traditional power sources have had harmful effect on Ozone layer and consequently led to the so called the (global warming).

II) Importance of Alternative Energy-It has to Important Sides

a) The environmental aspect: Obtaining electrical power depends on fuels which are obviously running out and cause environmental pollution in addition to the high costs of fuel and equipment. Therefore there has been too much emphasis on the electric power rationalizing methods. 
b) The economic Aspect-Solar cells system is different from the traditional one. Its primary costs are high but operation costs are low.

So we have to emphasize on the research on cheaper, cleaner and un expired energy. In Iraq, sunrise hours are $11-12$ a day and this suggests an important potential project for future generations.

However, tackling the issue of supply of clean and safe alternative power resources would be intercepted by some certain constraints like the direct reliance on oil resources and revenues for power supply and the concerns raised about the high costs of alternative power equipment's.

\section{III) Clean Alternative Energy Resources}

- Natural gas which is less polluting resource than gasoline. It can be suitable option for engine fuel an addition to its limited effect concerning the global warming.

- Ebb and tide. This phenomena can be utilized to produce electric power where stations are build at the river banks and gulf beaches.

- Plants. In the process of photo syntheses, light is used to transform $\mathrm{O}_{2}$ into (abumas) substance which helps supply the liquid fuel (the green fuel).

Alternative energy appears to be the suitable solution to the environment problem which comply with the ambitions to reduce health problems caused by power generation processes and related emissions which further cause environment pollution. The following research item will introduce important options to establish joint cooperation between the government and research centers at universities and other sectors in order to back up future energy strategy.

The above mentioned two researchers think that finding power alternative for oil has become an inevitable strategy for which many countries are currently looking for. The government has to be too much concerned about this issue. It is worthy mentioning that the conference held on $13^{\text {th }}$ August, 2008 tackled the sustainable biological fuel. Standards for biological fuel were introduced and included twelve standard development recommendations, they are:

- Biological fuel production operations need to be designed and carried out by all authorities related to planning and control process.

- Compared to traditional extracted fuel, biological fuel must lead to reduction in the emitted harmful gases.

- Biological fuel production must not breach human rights or labor rights and workers' prosperity must be considered.

- Biological fuel must contribute to the economic and social development of the country, cities rural areas and original citizens.

- Biological fuel production must not affect food security.

- Biological fuel production must not have negative effects on environment systems and variety and important environmental areas should be kept safe.

- Biological fuel production must motivate practices which lead to soil improvement and reform.

- Surface and underground water must be utilized properly.

- Environment pollution must be eliminated to a minimum limit. 
- Production must be done using most effective and cheapest methods. Production and performance efficiency considered in through all performance appraisal stages of the biological fuel.

- Biological fuel production operation must not violate land ownership rights.

\section{IV) Alternative Energy Resources}

Table 5 shows biological energy resources.

\section{Part Three: Alternative Energy Scopes in Iraq (Advantages and Disadvantages of Alternative Energy Production-Orientation)}

\section{1) As per Table 6 the justifications of orientation to alternative energy}

Our country is characterized by the abundance of different types of alternative energy. For example wind power can be obtained in different areas across the country, particularly in Basra. Wind speed rate varies from $8 \mathrm{M} / \mathrm{S}-12 \mathrm{M} / \mathrm{s}$ which can cause high electrical power production. Huge solar energy can also be obtained in the desert areas of Iraq and these regions are not exploited for any type of investment. An efficient investment of such resources would surely save large expenses to be spent on medical treatment of diseases caused pollution. The following table outlines the justifications of orientation to alternative energy production technologies.

Thus, the importance of multi-energy production resources which support range of services, products, and eco-friendly materials. What is surprising is that wind power was used in the ancient ages, when Alexander asked for power (energy) - as mentioned in the sacred Koran. The alternative energy, however, has got some disadvantages.

\section{2) Alternative Energy Using Defects}

Here are some of alternative energy use disadvantages:

- Cost of renewable energy erection works may be too high especially for individuals.

- It is unlikely to totally rely on alternative energy.

- It is often affected by weather conditions particularly when it is cloudy.

Table 5. That shows biological energy resources.

\begin{tabular}{|c|c|c|}
\hline No. & description & Energy product \\
\hline 1 & Biological fuel & $\begin{array}{l}\text { Ethanol, cellos, bagas, biological gasoline, botnal } \\
\text { Biological diesel, biological gas, maize firewood, bioso oil, vegetable } \\
\text { oil, straw, ethanol fuel }\end{array}$ \\
\hline 2 & Agricultural products & Sunflower, maize, selgem, soya bean, sugar cane \\
\hline 3 & Non food products & $\begin{array}{l}\text { Bongamia, jatrofa berbados, silver grass, themam, purple theyom, } \\
\text { Chinese wax, water lens, }\end{array}$ \\
\hline 4 & Technical product s & $\begin{array}{l}\text { Biological mass transformation into alkoholic fuel, heating systems } \\
\text { using biological mass, biological refinery, fisher-trobish operation, } \\
\text { industrial biological technology, ball grinder, thermo analysis }\end{array}$ \\
\hline 5 & Principal products & $\begin{array}{l}\text { Celluloses ethanol marketing, biological energy fuel content, energy } \\
\text { product, wood energy production }\end{array}$ \\
\hline
\end{tabular}

Source: [21] [22]. 
Table 6. The justifications of orientation to alternative energy.

\begin{tabular}{|c|c|c|c|c|}
\hline Advantages & Properties & Reasons & Benefits & requirements \\
\hline $\begin{array}{l}\text { Full replacement of } \\
\text { electric power } \\
\text { regarding water } \\
\text { heating in restaurants, } \\
\text { house, hotels and } \\
\text { hospitals-relying on } \\
\text { solar power since it is } \\
\text { clean. Therefore it } \\
\text { preserve environment. } \\
\text { It has no other risks } \\
\text { On human such as } \\
\text { electrical heaters } \\
\text { which can be deadly. } \\
\text { There is no difficulty } \\
\text { operating in operation } \\
\text { It works silently } \\
\text { No need for service } \\
\text { parts. It gives feeling } \\
\text { of comfort for the } \\
\text { availability of hot } \\
\text { water around } 24 \text { hours } \\
\text { time }\end{array}$ & $\begin{array}{l}\text { - The following are some } \\
\text { features renewable energy } \\
\text { (mediawiki.org)-ceaseless } \\
\text { - Friendly } \\
\text { - Non-waste producing } \\
\text { - Its use is not harmful to } \\
\text { living beings } \\
\text { - Sun, wind, ebb and tide } \\
\text { and underground power } \\
\text { activities all of which are } \\
\text { renewable energy } \\
\text { resources } \\
\text { - The price of solar energy } \\
\text { equipment mantling and } \\
\text { electricity bills will not } \\
\text { periodically } \\
\text { - It will not be affected by } \\
\text { the rise in fuels in the } \\
\text { world which may cause } \\
\text { the monthly bill to rise. } \\
\text { - By the use of alternative } \\
\text { renewable energy you will } \\
\text { not feel power waste } \\
\text { instead you will satisfied. } \\
\text { - -Oil, gas and coal supplies } \\
\text { and all other original } \\
\text { sources will once run out } \\
\text { but we can rely on the } \\
\text { new program } \\
\text { consequently. } \\
\text { - Government licensing } \\
\text { often assigned for housing } \\
\text { power projects. }\end{array}$ & $\begin{array}{l}\text { John Sherdan from Belard } \\
\text { Energy co., Canada mentioned } \\
\text { that reasons behind the } \\
\text { international alternative } \\
\text { energy growth are: } \\
\text { A. public opinion is addressed } \\
\text { to constriction of the massive } \\
\text { pollution } \\
\text { B. preservation of natural } \\
\text { resources } \\
\text { C. However, said Sherdon, fuel } \\
\text { cells play unique role in this } \\
\text { mixture of alternative energy } \\
\text { with all relevant properties } \\
\text { D. Sherd an emphasized that } \\
\text { other energy producing } \\
\text { techniques doesn't have the } \\
\text { advantages offered by fuel } \\
\text { cells: } \\
\text { A. high efficiency } \\
\text { B. credibility } \\
\text { D. energy quality } \\
\text { E. energy security } \\
\text { F. partiality } \\
\text { G. gradation } \\
\text { H. constraint-spot flexibility } \\
\text { I. economized consumption } \\
\text { J. noiseless-work } \\
\text { K. working with no running } \\
\text { parts } \\
\text { L. Power source is sun only }\end{array}$ & $\begin{array}{l}\text { Al-iSherbini } 2011 \\
\text { A. reduction of } \\
\text { electricity bill, } \\
\text { B. clean } \\
\text { environment } \\
\text { friendly resource } \\
\text { C. renewability } \\
\text { D. supply of solar } \\
\text { systems for water } \\
\text { heating } \\
\text { E. wind generators } \\
\text { F. under water } \\
\text { generators } \\
\text { G. no need for fuel } \\
\text { H. No waste is left } \\
\text { which are usually } \\
\text { caused by turbines } \\
\text { I. solar food stuff } \\
\text { J. sailboats } \\
\text { propelled by wind } \\
\text { power } \\
\text { K. Transport: } \\
\text { vehicles and jet } \\
\text { planes driven bys } \\
\text { solar power } \\
\text { L. Utilizing sea } \\
\text { waves power } \\
\text { M. Usage of plant } \\
\text { jatrova for oil and } \\
\text { power production }\end{array}$ & $\begin{array}{l}\text { The requirements } \\
\text { For the shift to renewable, clean energy } \\
\text { are related to the following: } \\
\text { A. Consolidation Of educating } \\
\text { programs on the environment in all of } \\
\text { state offices } \\
\text { B. Developing an integrate program } \\
\text { for environment-education addressed } \\
\text { to target social classes } \\
\text { C. integration of environmental } \\
\text { conceptions in curriculums } \\
\text { D. Establishing annual informative } \\
\text { program by ministry of environment } \\
\text { supported by press and other related } \\
\text { environment-related organizations } \\
\text { E. Developing education requirements } \\
\text { in the ministry of environment (books, } \\
\text { websites...) } \\
\text { F. Creation of clean energy efficiency } \\
\text { improvement programs } \\
\text { G. Providing government support to } \\
\text { develop clean energy resources } \\
\text { H. specifying incentive list } \\
\text { I. Emphasis on the work of } \\
\text { environment meteorology directorates } \\
\text { J. Revising licenses granted to the new } \\
\text { productive businesses, setting } \\
\text { provisions for licensing. } \\
\text { K. deforestation measures } \\
\text { L. Adopting the principle of green } \\
\text { business and ISO 140000 } \\
\text { M. Introducing the energy production } \\
\text { and storage conditions to the new } \\
\text { producing businesses }\end{array}$ \\
\hline
\end{tabular}

Source: Adapted by the researcher referring to [2].

- Solar cells require daily cleaning in case dust continues.

- It requires special batteries to sustain energy during the night and cloudy weather and such types batteries are too expensive.

- People with poor incomes cannot afford to use them.

- About $\$ 500$ is the amount needed for providing an average home with solar energy system. Economists and experts think that solar energy will not be an acceptable alternative for oil unless the cost of solar boards is reduced by five times.

3) The Economic, Social and Environmental effects of Alternative Energy 
The most significant economic advantage of energy in research is the stability in the traditional electricity production costs. New job opportunities may, in response, be created in this area. Most studies in this area confirm that there may be external paradox between the alternative energy application and the aims of economic, environment and social development. According to some experts this true but later, more positive tangible results may widely be achieved.

The temporary support for the renewable energy must be viewed as partial investment of better and cheaper electric supply system. In addition, $\mathrm{O}_{2}$ emission rates caused by the current energy are predicted reach the highest potion which contributes to the global warming.

As for social effects of the alternative energy, studies confirm that many countries including Iraq may be able to export solar energy-produced power in case natural resources are properly handled. And this may lead to establish powerful industries and in return create job opportunities.

In terms of the predicted environmental effect, solar energy-producing techniques, compared to traditional energy production do not take up large areas. Whereas areas occupied by wind power stations can be invested for purposes like farming and solar cells can be erected on building roofs and at facades.

So the alternative energy techniques including the solar energy have great economic, environmental and social benefits. On the other hand traditional energy can have negative effects on life activities in the sense that it consumes the resources of generations and, causes dangerous radiations which transfer across continents, [23] [24].

This requires specialists to put an end to the aggressive effects of traditional energy.

\section{Part Four-The Research Practical (Findings Outline and Analysis)}

This research section presents sample views concerning the availability of the four requirements of alternative energy (independent factor contents) which are (state policy, society education, academic support and funds); and the three dimensions of the dependent factor (economic, social and environment benefits). According the standard used, the study sample view will be presented for all items of the survey. We emphasize on less expressive statements regarding the possibility to provide alternative energy requirements through their dimensions in research society

1) General presentation (view points of research sample individuals on potential alternative power in Iraq)

The percentage of responses was determined in Table 8; while Table 7 shows the statistical analysis results i.e. standard deviations, mean values and the order of each of the seven dimensions. The mean value of potential availability of alternative energy requirements in public sectors in research reached (3.008) along with standard deviation value of (1.0154) as shown in Table 7.

Throughout Table 7, dimension (7) - the social benefits-appears to be the 
Table 7. Statistical analysis results.

\begin{tabular}{clcccc}
\hline No. & \multicolumn{1}{c}{ Dimension } & Symbol & $\begin{array}{c}\text { Mean value } \\
(\mathrm{x})\end{array}$ & $\begin{array}{c}\text { Standard } \\
\text { deviation (s.d) }\end{array}$ & $\begin{array}{c}\text { Order } \\
\text { (rank) }\end{array}$ \\
\hline 1 & Dimension (1) government policy & $\mathrm{X} 1$ & 2.700 & 1.2817 & Sixth \\
2 & Dimension (2): social culture & $\mathrm{X} 2$ & 2.860 & 1.0882 & Fifth \\
3 & Dimension 3: academic support & $\mathrm{X} 3$ & 3.120 & 0.733 & Fourth \\
4 & Dimension 4: funding & $\mathrm{X} 4$ & 2.040 & 1.009 & Seventh \\
5 & Dimension 5: economic benefits & $\mathrm{X} 5$ & 3.140 & 1.143 & Third \\
6 & Dimension 6: environmental benefits & $\mathrm{X} 6$ & 3.500 & 0.8391 & Second \\
7 & Dimension 7: social benefits & $\mathrm{X} 7$ & 3.700 & 0.9742 & First \\
& Total & & 3.008 & 1.0145 & \\
\hline
\end{tabular}

Source: Computer outputs in the spss statistical program.

most available in the sectors in research where mean value reached (3.7) and standard deviation (0.9742). Whereas the least available alternative energy dimension is the (fourth)-funding which achieved the minimum mean value of (2.040) with SD of (1.009).

With such results the two researchers think the alternative energy conception is relatively new at the level of the Arab homeland. In Iraq, it seems unlikely to fund a project like that since the government has no clear understanding regarding this conception.

1) The detailed presentation (the sample individual views on each of the seven dimensions) according to the statistic outputs of the research sample views $(\mathrm{n}=60)$. They are shown in Table 8.

Table 8 shows that item [21] -alternative energy provide clean atmospheres suitable for human health requirements, is the most expressive in relation with principle perception across the surveyed sectors in Basra.It got the highest mean value of (4.4) with St.D of (0.9961); whereas item 8 (our civil society organizations support alternative energy-related activities) is the least expressive regarding the sample response to the alternative energy culture in Basra. It received mean value of (2.38) and St. D value of (1.1045).

A detailed discussion on the results of each separate dimension is outlined as follows:

The independent dimension results analysis (z1): the four requirements for alternative energy availability $(\mathrm{x} 1-\mathrm{x} 4)$

- The first dimension (government policy $\mathrm{x} 1$ ). Table 8 shows that item (1) is the most expressive one about the alternative energy abundance in response to the government's policy regarding the basic sectors in Basra. This item, which implies the government's orientation towards new alternatives: solar, water, wind, biological, etc.), achieved higher mean value than the following items. It got mean value of (3.12) and S.d of (1.394) whereas item (2), which suggests that the government is inclined to reduce reliance on the traditional 
Table 8. Percentage of research sample responses.

\begin{tabular}{|c|c|c|c|c|c|c|c|c|c|c|}
\hline \multirow{2}{*}{$\begin{array}{l}\text { Dim./ } \\
\text { symbol }\end{array}$} & \multirow{2}{*}{\multicolumn{2}{|c|}{ Item no. \& symbol }} & \multicolumn{5}{|c|}{ Response degree } & \multirow{2}{*}{$\begin{array}{l}\text { Mean } \\
\text { value }\end{array}$} & \multirow{2}{*}{ St. Dev } & \multirow{2}{*}{ Rank } \\
\hline & & & 1 & 2 & 3 & 4 & 5 & & & \\
\hline \multirow{4}{*}{$\begin{array}{l}\text { Gov. } \\
\text { policy } \\
\text { X1 }\end{array}$} & $1 \mathrm{cl}$ & frequency & 6 & 15 & 8 & 9 & 12 & \multirow{2}{*}{3.12} & \multirow{2}{*}{1.3944} & \multirow{4}{*}{ sixth } \\
\hline & & Percent. & $12 \%$ & $30 \%$ & $16 \%$ & $18 \%$ & $24 \%$ & & & \\
\hline & $2 \mathrm{c} 2$ & Freq. & 4 & 18 & 12 & 10 & 6 & \multirow{2}{*}{2.92} & \multirow{2}{*}{1.1753} & \\
\hline & & Percent. & $8 \%$ & $36 \%$ & $24 \%$ & $20 \%$ & $12 \%$ & & & \\
\hline \multirow{4}{*}{$\begin{array}{c}\text { Society } \\
\text { Culture } \\
\text { X2 }\end{array}$} & $3 c 3$ & Freq. & 1 & 16 & 12 & 11 & 10 & \multirow{2}{*}{3.26} & \multirow[b]{2}{*}{1.1747} & \multirow{4}{*}{ fifth } \\
\hline & & Percent. & $2 \%$ & $32 \%$ & $24 \%$ & $22 \%$ & $20 \%$ & & & \\
\hline & $4 c 4$ & Freq. & 4 & 5 & 17 & 15 & 9 & \multirow{2}{*}{3.4} & \multirow{2}{*}{1.1429} & \\
\hline & & Percent. & $8 \%$ & $10 \%$ & $34 \%$ & $30 \%$ & $18 \%$ & & & \\
\hline \multirow{4}{*}{$\begin{array}{c}\text { Academic } \\
\text { Support } \\
\text { X3 }\end{array}$} & $5 c 5$ & Freq. & 1 & 7 & 23 & 12 & 7 & \multirow{2}{*}{3.34} & \multirow{2}{*}{0.9607} & \multirow{4}{*}{ fourth } \\
\hline & & Percent. & $2 \%$ & $14 \%$ & $46 \%$ & $24 \%$ & $14 \%$ & & & \\
\hline & $6 c 6$ & Freq. & 0 & 3 & 20 & 22 & 5 & \multirow{2}{*}{3.58} & & \\
\hline & & Percent. & $\mathrm{O} \%$ & $6 \%$ & $40 \%$ & $44 \%$ & $10 \%$ & & & \\
\hline \multirow{4}{*}{$\begin{array}{c}\text { Funding } \\
\text { X4 }\end{array}$} & $7 \mathrm{c7}$ & Freq. & 12 & 14 & 11 & 11 & 2 & \multirow{2}{*}{2.54} & \multirow{2}{*}{1.1988} & \multirow{4}{*}{ seventh } \\
\hline & & Percent. & $24 \%$ & $28 \%$ & $22 \%$ & $22 \%$ & $4 \%$ & & & \\
\hline & $8 \mathrm{c} 8$ & Freq & 11 & 19 & 13 & 4 & 3 & \multirow{2}{*}{2.38} & \multirow{2}{*}{1.1045} & \\
\hline & & Percent. & $22 \%$ & $38 \%$ & $26 \%$ & $8 \%$ & $6 \%$ & & & \\
\hline Econom- & $9 \mathrm{c} 9$ & Freq. & 1 & 5 & 12 & 16 & 16 & & & \\
\hline $\begin{array}{c}\text { 1C } \\
\text { Benefits }\end{array}$ & & Percent. & $2 \%$ & $32 \%$ & $24 \%$ & $32 \%$ & $32 \%$ & 5.02 & 1.0001 & thind \\
\hline $\mathrm{X} 5$ & $10 \mathrm{c} 10$ & Freq & 1 & 13 & 14 & 11 & 11 & & & \\
\hline & & percent & $2 \%$ & $26 \%$ & $28 \%$ & $22 \%$ & $22 \%$ & 5.00 & 1.1000 & \\
\hline Envi- & $11 \mathrm{cl1}$ & Freq & 0 & 4 & 11 & 22 & 13 & & & \\
\hline $\begin{array}{l}\text { ronment. } \\
\text { Benefits }\end{array}$ & & Percent & $0 \%$ & $8 \%$ & $22 \%$ & $44 \%$ & $26 \%$ & & & cerond \\
\hline X6 & $12 \mathrm{cl} 2$ & Freq & 0 & 3 & 13 & 22 & 12 & & & \\
\hline & & Percent. & $0 \%$ & $6 \%$ & $26 \%$ & $44 \%$ & $24 \%$ & & & \\
\hline Social & $13 \mathrm{c} 13$ & Freq & 0 & 1 & 15 & 20 & 14 & & & \\
\hline $\begin{array}{c}\text { Benefits } \\
\text { X7 }\end{array}$ & & Percent. & $0 \%$ & $2 \%$ & $30 \%$ & $40 \%$ & $28 \%$ & 3.94 & 0.8184 & \\
\hline & $14 \mathrm{c} 14$ & Freq & 1 & 3 & 5 & 20 & 21 & & & \\
\hline & & Percent. & $20 \%$ & $6 \%$ & $10 \%$ & $40 \%$ & $42 \%$ & & & \\
\hline
\end{tabular}

Source: Computer outputs in the spss statistical program.

energy, was the least expressive. It achieved (2.92) mean value along with S.d value of (1.753)

I think that these results can be considered as an indicator of unlikely application of alternative energy concept in Iraq since the government's current policy seems unbound to involve the alternative energy in the state's strategic plans. Furthermore the results implies the insufficient support offered to employees 
upon their inputs in the area of energy which may be caused by the unstable economic, political and security circumstances.

- The second dimension (society culture $\mathrm{x} 2$ )

According to Table 8, item (4) represents the most expressive one in terms of society agreement with the alternative energy. It reads: (society is bound to preserve energy to guarantee future generations rights) and its mean value reached (3.4) with S.D of (1.1429); whereas item (3), which implies (society think the present energy is threatened with running-out), had mean value of (3.26) with S.D of (1.1747)

- The third Dimension (Academic Support x3)

As given in the mentioned table, the item which received agreement among the sample individuals in regard with the academic support for the alternative energy efforts was item (3)which involves (the universities' scientific research centers orientation to environment damage-reduction energy). It scored mean value of (3.58) with SD rate of (0.7584) whereas mean value scored in item (5) was (3.34) and SD was (0.9607). This item suggests that (scientific research centers in our universities are interested in detection and use of alternative energy resources).

I think that the result is considered as scientific and technical clue which predicts more mature stage towards the local environment and alternative energy resources.

- The Fourth Dimension (funding $x 4$ )

This dimension appeared to be the worst among the other seven dimensions where analysis findings indicated that the dimension two items $(7,8)$ got the lowest mean values of ( 2.54 and 2.38 successively). The approximate responses of the sample individuals are related to the SD rates which were (1.1988) for item (7) and (1.1045) for item (8). Those results are generally attributed to the poorly supported issue of alternative energy.

This result reflects our disappointment and deep concerns about the coming generations future, a case that might probably be caused by the current government's financial and administrable policy. Therefore we call for our institutions to wake up and take their responsibilities to face these challenges.

2) The responsive dimension results analysis (z2): the predicted three benefits of alternative energy $(\mathrm{x} 7-\mathrm{x} 5)$

- The fifth Dimension (the economic benefits $x 5$ ).

The statistic analysis results indicate that variables of this dimension represented by the two items $(10-9)$ have achieved fair mean values compared to those scored by the previous dimensions. They reached (3.82-3.36) successively with SDs of $(1.0631-1.1563)$ and this may be attributed to the satisfaction of people who responded positively to the survey.

- The sixth Dimension (environmental benefits x6)

This dimension is represented by the two items [14] [16] which imply the amount of predicted environmental outputs when clean alternative energy is used. Item (11), which has the implication that alternative energy would help 
reduce the negative impact on the environment. Item (12) implies that alternative energy enable the industrial organization to respond to the environmental standard specifications (ISO-1400). The mean value for (item (11) was (3.88) with an SD of (0.8953) which suggests similar sample individual responses about the environmental benefits of alternative energy. The mean value and SD scored for item (12) were (3.86) and (0.8574) successively which suggests the use of alternative energy as an application of ISO-1400.

- The seventh Dimension (social benefits x7)

Scored the highest rates since this item was tried on all of the research variables where similar response figures were obtained. The percentages reached (42\% and 28\%) for items 14,13 successively and mean value and SD for item (14) were (14) and (0.9961) which refer to identical sample responses: alternative energy provide suitable clean atmospheres for human health requirements. Item (13) achieved mean value of (3.94) with SD of (0.8184) which suggests that (alternative energy is characterized by high degree of security compared to traditional energy).

The responsive research sample individuals supported the idea of turning to more secure energy.

\section{2) The Hypotheses verification}

To prove the credibility, the hypotheses which implies (the using of alternative clean, renewable energy will contributes to achievement of increase in the economic and environmental returns and reduces environment damage reasons. Table 9 shows test of the research results.

Table 9 shows variations in mean values of the seven sub-dimensions and the two main dimensions $(\mathrm{z} 1, \mathrm{z} 2)$ in relation with the standard value (3). Apparently there is positive indication of mean values and Sds obtained for the seven dimensions. The results referred to reverse statistic indication at error ratio of (0.05) which refers to uninterested policies expressed by the Iraqi government and authorities in other sectors regarding alternative energy adoption in spite of the available technical capabilities and convenient resources. The results in the table also shows the tight correlation among the research's seven dimensions and branch areas as clarified in the following table.

The results in Table 10 showed correlations between the two dimensions $\left(1^{\text {st }}\right.$ and $\left.2^{\text {nd }}\right)$ and the two dimensions ( $5^{\text {th }}$ and $7^{\text {th }}$ ) and finally between the dimensions $\left(6^{\text {th }}\right.$ and $\left.7^{\text {th }}\right)$ which is the strongest-it reached (0.437). Det. Coefficient between the interpreted dimensions and the responsive ones totally reached $\left(r^{2}=0.55\right)$. This implies a statistically acceptable strong correlation.

Accordingly, the hypotheses: (alternative, clean, renewable energy use contributes to achieving increase in social, economic and environmental returns and reduces the damages to environment) has been proved to be true.

\section{Conclusions}

1) Providing suitable technical efficiencies in institutions in research would 
Table 9. T-test of research results.

\begin{tabular}{ccccccc}
\hline Dimension & Item & $\begin{array}{c}\text { Mean } \\
\text { value }\end{array}$ & SD & $\begin{array}{c}\text { t. value } \\
\text { obtained }\end{array}$ & $\begin{array}{c}\text { Degree of } \\
\text { freedom }\end{array}$ & indication \\
\hline Government policy & C1 & 3.13 & 1.3944 & 0.609 & 49 & 0.546 \\
& C2 & 2.92 & 1.1753 & 0.481 & 49 & 0.632 \\
Society culture & C3 & 3.26 & 1.1747 & 1.565 & 49 & 0.124 \\
& C4 & 3.4 & 1.1429 & 2.475 & 49 & 0.071 \\
Academic support & C5 & 3.34 & 0.9607 & 2.603 & 49 & 0.016 \\
& C6 & 3.58 & 0.7584 & 5.408 & 49 & 0.000 \\
Funding & C7 & 2.54 & 1.1988 & -2.713 & 49 & 0.009 \\
& C8 & 2.38 & 1.1045 & -3.969 & 49 & 0.000 \\
Economic benefits & C9 & 3.82 & 1.0631 & 5.454 & 49 & 0.032 \\
& C10 & 3.36 & 1.1563 & 2.201 & 49 & 0.032 \\
Environment benefits & C11 & 3.88 & 0.8953 & 6.950 & 49 & 0.000 \\
& C12 & 3.86 & 0.8574 & 7.093 & 49 & 0.000 \\
Responsive variables & Z2 & 2.74 & 0.9649 & -1.905 & 49 & 0.000 \\
\hline Social benefits & C13 & 3.94 & 0.8184 & 8.122 & 49 & 0.000 \\
& $\mathrm{C} 14$ & 4.14 & 0.9961 & 8.318 & 49 & 0.000 \\
\hline
\end{tabular}

Source: Computer outputs in the spss statistical program.

Table 10. Pearson's correlation coefficient -relations among the seven dimensions.

\begin{tabular}{cccccccc}
\hline dimension & $\begin{array}{c}\text { Govern. } \\
\text { policy }\end{array}$ & $\begin{array}{c}\text { Society } \\
\text { culture }\end{array}$ & $\begin{array}{c}\text { Acad. } \\
\text { support }\end{array}$ & funding & $\begin{array}{c}\text { Econ. } \\
\text { benefits }\end{array}$ & $\begin{array}{c}\text { Environ. } \\
\text { benefits }\end{array}$ & $\begin{array}{c}\text { Soc. } \\
\text { Benefits }\end{array}$ \\
\hline Government policy & 1.000 & -0.206 & 0.078 & $0.372^{* *}$ & 0.196 & -0.142 & 0.025 \\
Society culture & -0.206 & 1.000 & -0.052 & 0.042 & -0.164 & -0.078 & -2.214 \\
Academic support & 0.078 & -0.052 & 1.000 & 0.098 & $0.327^{* *}$ & 0.189 & 0.157 \\
$\quad$ funding & $0.372^{* *}$ & 0.042 & 0.098 & 1.000 & $0.349^{*}$ & -0.145 & 0.012 \\
Economic benefits & 0.196 & -0.164 & $0.327^{* *}$ & $0.349^{*}$ & 1.000 & $0.372^{* *}$ & $0.313^{*}$ \\
Environment benefits & -0.142 & -0.078 & 0.189 & -0.145 & $0.372^{* *}$ & 1.000 & $0.437^{* *}$ \\
Social benefits & 0.025 & -0.214 & 0.157 & 0.012 & $0.313^{*}$ & $0.437^{* *}$ & 1.000 \\
\hline
\end{tabular}

Source: Computer outputs in the spss statistical program ${ }^{\star *}$ Correlation is significant at 0.01 (2-tailed) ${ }^{\star}$ Correlation is significant at 0.05 (2-tailed).

facilitate the applicability of the alternative, clean, renewable energy technology and can be an active alternative for the traditional energy to achieve the increasing energy requirements for the future.

2) Government's support and funding do not meet the level of ambitions of the institutions' staff. This was referred to in the statistical analysis results regarding dimension ( $\mathrm{x}$ four-independent variable $\mathrm{z} 1$ ). The results were frustrating in terms of the government's limited financial support for this clean tech- 
nology,

3) The analyzed results showed that alternative energy compared to traditional energy, could achieve significant degree of security which was referred to throughout the responses of sample in research. This sample is characterized by technical awareness and knowledge since it involves high proportions of specialists (engineers, technicians and ecological specialists). Responses were highly identical in the standard hierarchy-they reached (42\%) of the total responses and thus they represent an evident proof of those people's efficiency and readiness to make this type clean technology feasible.

4) Responses to the tried sample in the three sectors in Basra referred to the necessity for alternative energy which reflects the individuals' constant satisfaction with the huge economic incomes predicted to be saved by alternative energy.

5) According to the study results, there have been limited awareness and recognition of the alternative energy and environment issues in the part of staff working for Basra electricity directorate; and this was remarkable when engineers were reluctant to fill in the survey forms. Actually such responses raise deep feeling of anxiety in the part of researchers since they are convinced with the demand for an academic-technical cooperation between those professionals and university concerned activities to upgrade the pursuits in the environmental issues.

6) The study also showed limited governmental concerns about the way the garbage is processed and the poor cooperation addressed to tackle environment problems. Items ( $\mathrm{c} 2 \& \mathrm{c} 1$ ), dimension (1z) high lightened the tendency to rejection rather than agreement concerning response to the item: (The government is interested in new energy alternatives-solar, water, wind, ...) and the item: (The government is inclined to reduce reliance on the current energy).

7) It is necessary for government and institutions to include the energy topic in their future strategies, charter policies for its use rationalization and stop wasting it to preserve the future generations rights in addition to publicizing special culture on the importance of the alternative energy.

8) Making decisions that limit reliance on the traditional energy resources.

a) Encouraging the staff in the area of energy to effectively participate in the scientific sessions held at universities and research centers in order to support the technical-academic correlation aimed at development of alternative renewable energy culture.

b) Efficient processing and recycling of industrial wastes instead of leaving them scattered causing pollution and damages to human health.

c) The institutions in question have to invest the staff abilities by encouraging them and engaging them in the future natural resource-power projects to achieve the corporate objectives for sustainability. And this issue requires an inclusive perspective through which both government and people are responsible for its success. 
d) Enactment of laws which constrain overuse of all types of the current energy and reduce reliance on them. It does not mean cancellation of these resources rather it is meant to provide new auxiliary resources to satisfy the rising requirements for power. It is also important to preserve the future generations rights and thus institutions are all invited to bring this crucial issue to a tangible success.

\section{Acknowledgements}

I extend my sincere thanks to all the elements working in the three research institutions for their great cooperation in expressing their opinions on the tested questionnaire paragraphs and I acknowledge that this research will not penetrate any intellectual property of a particular researcher in any country, university or educational institution in the countries of the world

\section{Conflicts of Interest}

The author declares no conflicts of interest regarding the publication of this paper.

\section{References}

[1] Foreign Translated Resources.

[2] Al-Sharbini, A. and Aoiuth, S. (2020) Solar Energy Doubles to 3000 Giga-Watt by 2020 UAE Today Magazine.

[3] The Mediterranean Regional Office/WHO Report (2006) Health Care Secure Management. The Regional Office for Environment Protection, Amman.

[4] Anderson, E.K., Carlucci, A.P., De Risi, A. and Kyritsis, D.C. (2007) Synopsis of Experimentally Determined Effects of Electrostatic Charge on Gasoline Sprays. Energy Conversion and Management, 48, 2762-2768.

https://doi.org/10.1016/j.enconman.2007.07.009

[5] Kakarantzas, S.C., Grecos, A.P., Vlachos, N.S., Sarris, I.E., Knaepen, B. and Carati, D. (2007) Direct Numerical Simulation of a Heat Removal Configuration for Fusion Blankets. Energy Conversion and Management, 48, 2775-2783. https://doi.org/10.1016/j.enconman.2007.07.024

[6] Al-Mushal, S. and Abdul-Aziz, B. (2011) Alternative Energy and Healthy Environment.

[7] Denton, J.C., Rakopoulos, C.D., Tsatsaronis, G. and Frangopoulos, C.A. (2006) 19th International Conference on Efficiency, Cost, Optimization, Simulation and Environmental Impact of Energy Systems. Energy Conversion and Management.

[8] Alwan, A.K. (2011) Environment Pollution: Challenge and Treatment. Quoted from lifeye10.gmail.com.

[9] Aubaid, M.F. (2003) Scientific Research Skills. World Studies Academy, Gaza.

[10] Al-Azeem, A. and Ibrahim, H. (2009) The Ecological Dimensions of Disease. Human Science Magazine, Fourth Year No. 245, Algeria.

[11] Abdul-Majeed, Q. (2005) Entrance to the Overall Economic Policies. Analytic Study University Press.

[12] Huedi, M. (2004) Altefseer Al maeen lilwaedheen wel mutaedheen. The Sacred Ko- 
ran in Thi Aqurba Publications, Riyadh.

[13] Talbi, M. and Sahel, M. (2008) The Importance of Renewable Energy in Environment Protection for Sustainability. Albahith Magazine, No. 6, Al-Bulayda University, Algeria.

[14] Douglass Moshet, F. Sustainability Principles. Translated by Behaa Shahin.

[15] Kang, T. and Kyritsis, D.C. (2007) A Combined Experimental/Computational Investigation of Stratified Combustion in Methane-Air Mixtures. Energy Conversion and Management, 48, 2769-2774. https://doi.org/10.1016/j.enconman.2007.07.018

[16] Ort, M. (2008) We Have to Increase Efficiency. German Magazine No. 2, Societies Press, Frankfurt.

[17] Hatton, G.D., Shortland, A.J. and Tite, M.S. (2008) The Production Technology of Egyptian Blue and Green Frits from Second Millennium BC Egypt and Mesopotamia. Journal of Archaeological Science, 35, 1590-1604.

https://doi.org/10.1016/j.jas.2007.11.008

[18] US Department Energy (2009) Smart Grid System Report. USA.

[19] Naylor, J. (1999) Management "Financial Times". Prentice Hall, Upper Saddle River.

[20] Pérez, D. (2010) An Investigation of the Impact of Machismo and Caballerismo on the Health Care Seeking Behaviors of Latino Men Residing in Genessee County. University of Michigan.

[21] Dugmor, K. (1977) Welcome to Solar Energy Equipment est.1977.

[22] http://wikipedia.org./wik

[23] Environmental Engineering Society Website. http://mediawiki.org

[24] Anagnostopoulos, J.S. and Papantonis, D.E. (2007) Pumping Station Design for a Pumped-Storage Wind-Hydro Power Plant. Energy Conversion and Management, 48, 3009-3017. https://doi.org/10.1016/j.enconman.2007.07.015 